\title{
EFEKTIVITAS PROMOSI TIKET.COM TERHADAP KEPUTUSAN WISATAWAN DOMESTIK DALAM PEMBELIAN TIKET PESAWAT MENUJU BALI
}

\author{
Ni Luh Putu Riska Riana Paramita ${ }^{1}$, I Wayan Suardana ${ }^{2}$, I Made Sendra ${ }^{3}$ \\ ${ }^{1}$ Email: riskarianap@gmail.com \\ Program Studi S1 Industri Perjalanan Wisata, Fakultas Pariwisata, Universitas Udayana \\ ${ }^{2}$ Email: suardana_ipw@unud.ac.id \\ Program Studi S1 Industri Perjalanan Wisata, Fakultas Pariwisata, Universitas Udayana \\ ${ }^{3}$ Email: sendramade65@gmail.com \\ Program Studi S1 Industri Perjalanan Wisata, Fakultas Pariwisata, Universitas Udayana
}

\begin{abstract}
The purpose of this study is to determine the effectiveness of promotion Tiket.com through several stages, such as: identification dimensions empathy, persuasion, impact, and communication. Further reviewed how the effectiveness of promotion Tiket.com it can affect the decision to buy air tickets to Bali. Data collection techniques used obeservation, interviews, questionnaires, literature studies and documentation. Data collection techniques use non-probability sampling with accidental sampling procedure. The analysis technique used quantitative descriptive analysis and multiple linear regression analysis. The result of this study shows that the dimension of empathy (x1) has a positive and significant effect of 0.001 on buying decisions $(\mathrm{y})$, persuasion dimension $(\mathrm{x} 2)$ has a positive and significant effect of 0.001 on buying decisions (y), impact dimension (x3) significant $0,041$ to the buying decision (y) and the last dimension of communication ( $\mathrm{x} 4)$ have a positive and significant effect of 0.000 on buying decision (y). From the EPIC model is the face of communication is the biggest factor influencing the decision of tourists to buy ticket through the website Tiket.com. This is because the communication contained in promotion Tiket.com easy to understand and attached to the memory of tourists to use the website Tiket.com when buying air tickets if want to travelling.
\end{abstract}

Abstrak : Penelitian ini bertujuan untuk mengetahui efektivitas promosi Tiket.com melalui beberapa tahapan, yaitu : identifikasi dimensi emphaty, persuasion, impact, dan communication. Selanjutnya dikaji bagaimana efektivitas promosi Tiket.com dapat mempengaruhi keputusan pembelian tiket pesawat menuju Bali. Teknik pengumpulan data menggunakan observasi, wawancara, kuesioner, studi kepustakaan dan dokumentasi. Teknik pengumpulan data menggunakan non-probability sampling dengan prosedur accidental sampling. Teknik analisis menggunakan analisis deskriptif kualitatif dan analisis regresi linier berganda. Hasil dari penelitian ini menunjukan bahwa dimensi empathy (x1) berpengaruh positif dan signifikan sebesar 0,001 terhadap keputusan pembelian (y), dimensi perssuasion (x2) berpengaruh positif dan signifikan sebesar 0,001 terhadap keputusan pembelian (y), dimensi impact (x3) berpengaruh positif dan signifikan sebesar 0,041 terhadap keputusan pembelian $(\mathrm{y})$, dan yang terakhir dimensi communication $(\mathrm{x} 4)$ berpengaruh positif dan signifikan sebesar 0,000 terhadap keputusan pembelian (y). Dari EPIC model tersebut segi communication merupakan factor yang paling besar mempengaruhi keputusan wisatawan untuk membeli tiket melalui website Tiket.com, hal ini dikarenakan komunikasi yang terdapat dalam promosi Tiket.com mudah untuk dimengerti dan melekat pada ingatan wisatawan untuk menggunakan website Tiket.com ketika membeli tiket pesawat jika melakukan perjalanan wisata.

Keywords: effectiveness, promosion, EPIC model, buying decision, tiket.com. 


\section{PENDAHULUAN}

Perkembangan pariwisata saat ini sudah semakin pesat, baik dari segi pelayanan maupun teknologinya. Kebutuhan pariwisata khususnya di bidang perjalanan semakin lama semakin cepat pelayanannya, maka teknologi pun menyesuaikan untuk memenuhi kebutuhan tersebut. Pesatnya perkembangan pertumbuhan pengguna internet dibuktikan dengan hasil survei yang diselenggarakan oleh Asosiasi Penyelenggara Jasa Internet Indonesia (APJII) Tahun 2017. Terdapat Jumlah pengguna internet tahun 2017 adalah 143,26 juta user atau sekitar 54,68\% dari total jumlah penduduk Indonesia sebesar 262 juta jiwa.

Fenomena ini menjadikan banyak pebisnis pariwisata mulai mengembangkan usaha-usaha yang dikelola secara offline mulai ke arah online. Disamping untuk menghemat biaya sekaligus untuk mempermudah para konsumen dalam menikmati produkproduk yang ditawarkan dan para pelaku usaha dapat memberikan pelayanan terbaik bagi konsumennya. Perkembangan tersebut membuat dunia komunikasi yang semakin lama semakin mengalami perubahan pesat menjadi berbasis digital hingga muncul istilah pedagangan eletronik (e-commerce). Menurut McLeod (2008) dalam Miftah (2015), perdagangan elektronik atau yang disebut juga e-commerce adalah penggunaan jaringan komunikasi dan computer untuk melaksanakan proses bisnis. Pengertian e-commerce adalah menggunakan internet dan komputer dengan browser web untuk mengenalkan, menawarkan, membeli sebuah pasar internasional. Bisnis dapat dijalankan tanpa harus terbentur pada batas Negara dengan adanya teknologi digital. Biaya operasional dapat ditekan sedikit mungkin, mengurangi penggunaan kertas dalam berbagai aktifitas pengerjaan mulai dari mendesain, memproduksi, pengiriman, pendistribusian hingga marketing.

Kelebihan dalam melakukan pemesanan tiket pesawat melalui online travel agent sebagai berikut; a). Konsumen dapat dengan mudah melakukan pemesanan secara fleksibel. Fleksibel yang dimaksud adalah dapat dilakukan dimana saja dan kapan saja. Konsumen juga dapat memilih jadwal penerbangan, harga dan maskapai penerbangan dengan bebas sesuai dengan keinginan. Konsumen juga dapat memilih cara pembayaran sesuai yang mereka inginkan. b). Konsumen tidak perlu jauhjauh pergi ke kantor biro perjalanan ataupun ke travel agent untuk memesan tiket pesawat. Cukup membutuhkan laptop dan smartphone yang sudah tersambung internet dan lakukan pemesanan sambil bersantai di rumah atau tempat bekerja. c). Tiket dapat dipesan ke penyedia jasa yang akan melayani pemesanan konsumen selama 24 jam. Bahkan tidak jarang penyedia jasa akan membantu konsumen untuk melakukan pemesanan, Konsumen hanya perlu memberikan data dan melakukan pembayaran tanpa takut kehabisan kuota pesawat. d). Dengan e-ticket konsumen tidak perlu membawa tiket kemana-mana. Apabila tiket hilang, konsumen dapat print kembali dan tidak dikenakan biaya tambahan. Bahkan konsumen dapat melakukan check-in dan memilih nomor kursi secara online pula, akan tetapi check-in online belum didukung oleh semua maskapai penerbangan.

Penjualan tiket pesawat secara online merupakan salah satu model ecommerce yang elegan. Banyak agen perjalanan yang menyediakan layanan pembelian tiket pesawat dengan berbagai jenis hotel dan daerah nasional atau internasional secara online melalui sebuah website. Begitu pula salah satu agen perjalanan yang populer di Indonesia yakni tiket.com. Situs tiket.com menyediakan layanan pemesanan hotel, tiket pesawat, tiket kereta api, penyewaan 
mobil yang berbasis di Jakarta, Indonesia. Situs tiket.com dibentuk pada bulan Agustus 2011. Dengan tiket.com, pengguna internet sangat dimudahkan untuk merencanakan perjalanan karena tak hanya melayani tentang informasi tiket pesawat, di website tiket.com juga melayani penjualan pemesanan hotel serta tiket kereta api bahkan penyewaan mobil sehingga sangat memudahkan pengguna internet untuk merencanakan perjalanan mereka. Maskapai yang tergabung dalam penjualan tiket pesawat di tiket.com yaitu, dalam penerbangan domestik diantaranya Garuda Indonesia, Lion Air, Citilink, Air Asia, Batik Air, Sriwijaya, Wings Air, Nam Air, sedangkan penerbangan internasional diantaranya Garuda Indonesia, Air Asia, Lion Air, KLM, Malaysia Airline, Singapore Airline, Silkair, Cathay Pacific, Xiamen Air, China Southen Airline, Philipine Airline, Jet star, Virgin Australia, Qantas Airways, China Airline, Emirates, Evaair, Thai Airways, British Airways, All Nippon Airways, dan masih banyak lagi penerbangan yang dilayanani oleh tiket.com.

Dilihat dari situs traffic rank analyst www.similiarweb.com, berikut ini ditampilkan perbandingan peringkat atau ranking dari seberapa popular suatu website dibandingkan dengan website lainnya yang sejenis.

Tabel 1. Traffic Rank Website Online Travel Agent

\begin{tabular}{llr}
\hline $\begin{array}{l}\text { Nama Website } \\
\text { OTA }\end{array}$ & $\begin{array}{l}\text { Peringkat } \\
\text { Global }\end{array}$ & \multicolumn{2}{l}{$\begin{array}{l}\text { Peringkat di } \\
\text { Indonesia }\end{array}$} \\
\hline traveloka.com & 1.838 & 59 \\
\hline tiket.com & 4.721 & 112 \\
\hline pegipegi.com & 17.990 & 433 \\
\hline
\end{tabular}

Sumber : www.similiarweb.com (2018)

Berdasarkan tabel di atas terlihat tiket.com menempati urutan ke 112 dimana peringkat tersebut merupakan peringkat kedua dari semua situs online travel agent sejenis lainnya. Peringkat pertama ditempati oleh pesaingnya yaitu traveloka.com dengan urutan ke 59. Sebagaimana diketahui tiket.com yang sudah terlebih dahulu memasuki pasar online travel agent sebelum traveloka.com diluncurkan, akan tetapi tiket.com mendapat posisi kedua setelah traveloka.com. Sementara pada tahun yang sama pegipegi.com masih jauh tertinggal pada urutan ke 433 di Indonesia.

Tiket.com telah melakukan berbagai macam promosi diantaranya melalui iklan di youtube, televisi, media cetak, email, dan media internet lainnya. Promosi merupakan salah satu variabel dalam bauran pemasaran yang sangat penting dilaksanakan oleh perusahaan dalam memasarkan produk jasa (Rambat, A.hamdani 2006:120). Salah satu program andalan promosi dari tiket.com adalah program TIX Point.

Tidak hanya program TIX saja, program promosi lainnya dari tiket.com juga menawarkan diskon untuk pembelian tiket pesawat, tiket.com memberikan potongan harga yang tidak tanggungtanggung hingga Rp.500.000,- untuk harihari tertentu dengan syarat dan ketentuan berlaku.

Efektif atau tidaknya promosi tiket.com sebagai sumber informasi yang dibutuhkan konsumen, tergantung pada informasi yang disajikan. Efektivitas dalam kegiatan promosi memang dibutuhkan suatu perusahaan untuk memperkenalkan produk barang atau jasa yang baru dihasilkan kepada masyarakat luas. Menurut Gibson (1984) dalam Fajar (2012:23) efektivitas adalah suatu alat yang mengukur keberhasilan atau kegagalan suatu perusahaan terhadap kegiatan yang dilakukan perusahaan. Dapat dikatakan bahwa efektifitas merupakan alat pengukur keberhasilan dalam melakukan suatu tindakan.

Melihat fenomena situs tiket.com yang berada di peringkat 112, sedangkan situs sejenis yaitu traveloka.com yang berada di peringkat 59. Penulis tertarik untuk meneliti efektifitas promosi di 
website tiket.com terhadap keputusan pembelian tiket pesawat.

\section{METODE PENELITIAN}

Penelitian ini, akan meneliti website Tiket.com yang merupakan situs pencarian harga tiket yang terlengkap dibandingkan situs agent perjalanan online yang lainnya. Situs tiket.com dibentuk pada bulan Agustus 2011. Dengan Tiket.com, pengguna internet sangat dimudahkan untuk merencanakan perjalanan karena tak hanya melayani tentang informasi tiket pesawat. Website Tiket.com juga melayani penjualan pemesanan hotel serta tiket kereta api bahkan penyewaan mobil sehingga sangat memudahkan pengguna internet untuk merencanakan perjalanan mereka. Adapun variabel yang diteliti yaitu, variabel efektifitas promosi (EPIC Model) dan keputusan pembelian.Variabel efektifitas promosi (EPIC Model) dibagi menjadi empat sub-variabel yaitu, 1) Empathy, 2) Persuation, 3) Impact, dan 4) Communications. Variabel keputusan pembelian dibagi dalam empat subvariabel yaitu: 1) Kemantapan pada sebuah produk, 2) Kebiasaan dalam membeli produk, 3) Merekomendasikan kepada orang lain, dan 4) Melakukan pembelian ulang.

Teknik pengumpulan data yang digunakan dalam penelitian ini yaitu: 1) Observasi, teknik observasi yang digunakan peneliti adalah teknik non partisipan. 2) Wawancara, dengan cara melakukan tanya jawab dengan pihak pengelola tiket.com serta dengan pengguna/pelanggan tiket.com untuk mendapatkan informasi tentang efektifitas promosi di tiket.com. 3) Kuesioner, teknik ini digunakan untuk memperoleh data dengan menyebarkan kuisioner kepada wisatawan nusantara melalui google form yang berisi tentang pendapat pelanggan tiket pesawat, promosi dan keputusan pembelian tiket pesawat di situs Tiket.com. Penyebaran kuisioner dilakukan sebanyak 200 kuesioner. 4)
Studi kepustakaan yaitu, mencari informasi dengan berbagai buku atau literatur - literatur yang berkaitan dengan penelitian ini dan dapat mendukung kelengkapan dari penelitian ini, dan 5) Dokumentasi, dengan pengambilan gambar atau photo mengenai isi dari situs Tiket.com dan keterkaitan terhadap penelitian ini.

Teknik penentuan dan pengambilan sampel dilakukan secara non-probability sampling dengan prosedur accidental sampling. Responden yang menjawab pertanyaan kuesioner, yaitu wisatawan nusantara yang menjadi pelanggan tiket pesawat di Tiket.com. Responden yang dipilih adalah pemilik akun aktif yang pernah membeli tiket pesawat di Tiket.com. Pemilihan responden dilakukan secara kebetulan (accidental sampling) dengan memberikan kuesioner online kepada setiap akun yang menjadi pelanggan tiket pesawat di Tiket.com. Penentuan jumlah sampel menurut J.Supranto (2006), yaitu 5-10 dikali jumlah indikator. Adapun jumlah sampel dalam penelitian ini adalah: 20 indikator x $10=200$, maka sampel untuk penelitian ini mengambil sampel sebanyak 200 wisatawan yang menggunakan situs Tiket.com untuk memesan tiket pesawat. Teknik analisis dalam penelitian ini menggunakan dua jenis teknik analisis data yaitu, pendekatan kualitatif untuk mengolah data hasil wawancara dan analisis regresi linier berganda dengan bantuan SPSS versi 17.0 untuk mengolah data hasil penyebaran kuesioner.

\section{HASIL}

Tiket.com, nama ini dibeli pada tahun 2007 oleh Wenas Agusetiawan. Pada bulan Agustus 2011, diresmikan menjadi perusahaan bernama PT.Global Tiket Network dan kemudian diresmikan menjadi situs Tiket.com yang resmi beroperasi terhitung desember 2011. Situs Tiket.com ini sendiri server nya berada di Singapura dan terkenal sebagai situs yang 
menjadi solusi online dalam penyediaan tiket penerbangan, booking hotel, tiket kereta api sampai dengan tiket untuk event dan konser bisa didapatkan di situs ini.

Tiket.com ini awalnya didirikan oleh 7 orang Co-founder, dimana empat Co-founder masih menjalankan sampai sekarang, yaitu Wenas Agusetiawan, Dimas Surya Yaputra, Natali Ardianto dan Mikhael Gaery Undarsa. Pada awalnya, sosok Wenas Agusetiawan yang membeli domain Tiket.com dan beberapa domain cantik lainnya, memasangkan landing page dan analytical tools yang mengukur berapa visitor yang mengunjungi domain name tersebut. Didapatkan bahwa Tiket.com memiliki banyak peminat dan kemudian ia mengajak beberapa koleganya untuk bekerjasama membuat sebuah situs web khusus untuk melayani pemesanan tiket pesawat dan juga kereta api. Tiket.com ini adalah merupakan salah satu rekan bisnis KAI (Kereta Api Indonesia) yang resmi di nusantara. Tidak hanya bekerjasama dengan Kereta Api Indonesia, situs Tiket.com juga telah bekerjasama dengan berbagai maskapai penerbangan yang ada di Indonesia. Tujuannya untuk memudahkan masyarakat yang ingin memesan tiker pesawat dengan menggunakan internet. Lebih praktis dan lebih lengkap jika pilihan maskapainya terbilang variatif.

Sampai saat ini, situs Tiket.com diketahui memiliki lebih dari jutaan pengguna jasa layananan travel online yang aktif dan juga memiliki kerjasama dengan PT KAI, dan beberapa maskapai nasional, diantaranya Air Asia, Citilink, Lion air, Tiger, Mandala, Sriwijaya dan Merpati. Tercatat juga memiliki jaringan kemitraan bersama dengan lebih dari 200.000 hotel dalam dan luar negeri. Merencanakan liburan pun jauh lebih mudah dan praktis, cukup mengunjungi satu situs, maka bisa mendapatkan tiket pesawat, booking hotel dan tiket lainnya dalam satu waktu yang sama.

Lebih dari enam tahun beroperasi, dilihat dengan menggunakan catatan dari www.alexa.com, yakni sebuah situs khusus yang menyediakan informasi ranking dari setiap situs internasional, maka situs Tiket.com telah tercatat sebagai sebuah situs yang menempati urutan rank global ke 11.841. Sudah tentu itu merupakan sebuah prestasi yang luar biasa karena menunjukkan situs tersebut stabil. Bahkan untuk ranking di Indonesia menempati urutan website terpoluler ke 180 di Indonesia. Melihat perkembangan teknologi yang semakin canggih dan semakin meningkatnya pengguna situs Tiket.com, tak bisa dipungkiri jika Tiket.com akan semakin berkembang dan tumbuh ke depannya. (Sumber : https://www.ilmu.com/sejarah-tiket-comhingga-kini/)

\section{Karakteristik Pengguna Tiket.com}

$\begin{array}{rrr}\text { Berdasarkan } & \text { hasil } & \text { penyebaran } \\ \text { kuesioner } & \text { kepada } & 200\end{array}$ responden/wisatawan yang disebar melalui kuesioner online pada penelitian ini, wisatawan asal Jakarta yang paling mendominasi dengan persentase sebesar $20 \%$, kemudian disusul dengan wisatawan asal Jawa Tengah dan Jawa Barat masing masing $18,5 \%$, wisatawan asal Jawa Timur sebesar $13,5 \%$, wisatawan asal sebesar NTB 6,5\%, wsiatawan asal Sumatera Utara sebesar 6\%, wisatawan asal Sumatera Barat sebesar 3,5\%, wisatawan asal Sumatera Selatan sebesar 3,5\%, wisatawan asal Sulawesi sebesar 3\%, wisatawan asal NTT sebesar 2,5\%, wisatawan asal Kalimantan sebesar 2,5\%, wisatawan asal Papua sebesar 1\%, wisatawan asal Maluku sebesar $0,5 \%$, dan wisatawan asal Riau sebesar 0,5\%. Berdasarkan jenis kelamin, wisatawan perempuan lebih mendominasi daripada laki - laki. Wisatawan perempuan dengan jumlah sebesar $60 \%$, sedangkan laki - laki sebesar $40 \%$.

Selanjutnya, berdasarkan status, didominansi oleh wisatawan yang belum menikah daripada wisatawan yang sudah menikah. Wisatawan yang belum menikah dengan jumlah sebesar $70 \%$ dan 
wisatawan yang sudah menikah sebesar $30 \%$. Berdasarkan usia, pengguna tiket.com didominasi oleh wisatawan yang berusia 17 s/d 27 tahun sebesar 75\%, kemudian disusul wisatawan dengan usia $28 \mathrm{~s} / \mathrm{d} 38$ tahun sebesar 14\%, dan wisatawan yang berumur $39 \mathrm{~s} / \mathrm{d} 55$ tahun sebesar $11 \%$.

Pengguna tiket.com berdasarkan pendidikan terakhir didominasi oleh wisatawan yang pendidikannya S1 / S2 sebesar 47\%, kemudian disusul dengan pendidikan terkahir SMA sebesar 34\% dan Diploma 20\%. Berdasarkan profesi atu pekerjaan, pengguna lebih banyak bekerja sebagi karyawan sebesar 41,5\%, kemudian disusul dengan pelajar sebesar 35,5\%, wirausaha sebesar $17,5 \%$, pengajar sebesar $2 \%$, tidak bekerja sebesar $2 \%$, dan sebagai dokter $1,5 \%$. Selanjutnya, berdasarkan sumber infomasi mengenai tiket.com, wisatawan mendapat informasi melalui iklan di televisi lebih mendominasi yaitu sebesar 32,5\%, kemudian disusul dengan sumber informasi melalui iklan di internet sebesar 25\%, dari teman/kerabat sebesar 24,5\%, melaui iklan di media cetak sebesar $17 \%$, dan laiinya sebesar $0,5 \%$.

\section{Uji Validitas dan Reliabilitas}

Uji Validitas digunakan untuk mengetahui sah atau valid tidaknya suatu kuesioner. Item kuesioner dinyatakan valid apabila masing-masing item tersebut memiliki taraf signifikansi $\alpha \leq 0,05$ dan nilai $r_{\text {hitung }}$ lebih besar dari nilai $r_{\text {tabel. }}$.

Berdasarkan uji validitas dan reliabilitas dengan menggunakan program SPSS versi 17.0 dengan sampel 200 responden pada 20 indikator mendapatkan hasil bahwa seluruh indikator dinyatakan valid dengan r-hitung lebih besar daripada r-tabel. Hasil uji reliabilitas dalam penelitian ini memiliki kriteria Alpha Cronbach $>0,5$ maka akan dinyatakan reliabel, untuk hasil reliabilitas dalam penelitian ini mendapatkan hasil Alpha Cronbach sebesar 0.959 maka hal ini sudah memenuhi syarat penelitian dan dapat melanjutkan ketahap berikutnya yaitu analisis regresi berganda.

\section{Uji Asumsi Klasik}

Hasil uji asumsi klasik dalam penelitian ini terdapat tiga uji normalitas, uji multikolineritas, dan uji heteroskedastisitas. Hasil uji normalitas menyatakan bahwa variabel-variabel data pada penelitian ini dinyatakan normal dikarenakan nilai Sig atau Asymp. Sig. (2tailed) pada uji Kolmogorov- Smirnov sebesar 0,819 dimana lebih besar dari 0,05. Hasil uji multikolineritas menyatakan bahwa model regresi penelitian ini tidak terjadinya multikolinieritas dimana nilai VIF dari sebesar X1 2,642, X2 2,942, X3 3.055, X4 3,011, semuanya dibawah nilai 10 dan nilai tolerance value sebesar $\mathrm{X} 1$ 0,379, X2 0,340, X3 0,327, X4 0,332, semuanya diatas 0,1 . Hasil uji heteroskedastisitas menyatakan bahwa masing-masing variabel tidak adanya gejala heteroskedastisitas nilai signifikansi dari masing-masing variabel $\geq 0,05$ dengan menggunakan uji Glesjer.

\section{Analisis Regresi Berganda}

Analisis regresi berganda digunakan untuk mengetahui pengaruh variabel Empati (X1), Persuasi (X2), Dampak (X3) dan Komunikasi (X4) terhadap variabel keputusan pembelian (Y).. Adapun persamaan regresi berganda pada penelitian ini adalah $\mathrm{Y}=5,075+$ $0,541 \mathrm{X} 1+0,572 \mathrm{X} 2+0,315 \mathrm{X} 3+0,834$ $\mathrm{X} 4+\mathrm{e}$, dengan demikian, dapat dijelaskan bahwa empati berpengaruh terhadap keputusan pembelian sebesar 0,541. Persuasi berpengaruh terhadap keputusan pembelian sebesar 0,572. Dampak berpengaruh terhadap keputusan pembelian sebesar 0,315 dan komunikasi berpengaruh terhadap keputusan pembelian sebesar 0,834 .

\section{Analisis Koefisien Determinasi}

Hasil analisis koefisien determinasi dalam penelitian ini menyatakan bahwa besar nilai pengaruh empati, persuasi, 
dampak dan komunikasi terhadap keputusan pembelian tiket melalui website Tiket.com sebesar 69,5\%. Dengan nilai Adjusted R Square sebesar 0,695 bila dijadikan persentase menjadi $69,5 \%$. Sisa persentase tersebut sebesar 30,5\% menunjukan pengaruh dari variabel lain yang tidak dipaparkan pada penelitian ini.

\section{Uji Hipotesis}

Uji hipotesis dalam penelitian ini terdapat dua uji yaitu uji $t$ dan uji f. Hasil uji $t$ pertama yaitu pengaruh empati terhadap keputusan pembelian. Terlihat bahwa nilai thitung sebesar 3,299 > dari t tabel sebesar 1,652, dengan demikian dari hasil tersebut dapat disimpulkan hipotesis H1 diterima yang berarti variabel empati memiliki pengaruh yang positif dan signifikan terhadap keputusan pembelian tiket pesawat melalui website Tiket.com dan layak dijadikan penentu dari variabel keputusan pembelian. Hasil uji t kedua yaitu pengaruh persuasi terhadap keputusan pembelian menunjukan bahwa $\mathrm{t}$ hitung sebesar 3,326> dari t tabel sebesar 1,652. Dengan hasil tersebut dapat disimpulkan hipotesis $\mathrm{H} 1$ diterima yang berarti variabel persuasi memiliki pengaruh yang positif dan signifikan terhadap keputusan pembelian tiket melalui website Tiket.com dan layak dijadikan penentu dari variabel keputusan pembelian. Hasil uji $t$ ketiga yaitu pengaruh dampak terhadap keputusan pembelian menunjukan bahwa $t$ hitung sebesar 2,056 > dari t tabel sebesar 1,652. Dari hasil tersebut dapat disimpulkan hipotesis $\mathrm{H} 1$ diterima yang berarti variabel dampak memiliki pengaruh yang positif dan signifikan terhadap keputusan pembelian tiket melalui website Tiket.com dan layak dijadikan penentu dari variabel keputusan pembelian. Hasil uji t keempat yaitu pengaruh komunikasi terhadap keputusan pembelian menunjukan bahwa $\mathrm{t}$ hitung sebesar 5,321> dari t tabel sebesar 1,652. Dengan hasil tersebut dapat disimpulkan hipotesis $\mathrm{H} 1$ diterima yang berarti variabel komunikasi memiliki pengaruh yang positif dan signifikan terhadap keputusan pembelian tiket melalui website Tiket.com dan layak dijadikan penentu dari variabel keputusan pembelian.

Hasil uji $\mathrm{F}$ menunjukkan keempat variabel secara bersamaan berpengaruh terhadap keputusan pembelian yang menunjukan bahwa $f$ hitung sebesar 114,523. Dari hasil tersebut dapat disimpulkan hipotesis $\mathrm{H} 1$ diterima yang berarti terdapat pengaruh variabel bebas yaitu: empati (X1), persuasi (X2), dampak (X3) dan komunikasi (X4), secara simultan terhadap variabel terikat yaitu keputusan pembelian Tiket melalui website Tiket.com (Y).

Berdasarkan hasil analisis regresi berganda, didapat suatu persamaan $\mathrm{Y}=$ $5,075+0,541 \mathrm{X} 1+0,572 \mathrm{X} 2+0,315 \mathrm{X} 3$ $+0,834 \mathrm{X} 4+\mathrm{e}$, yang menyatakan bahwa variabel empati, persuasi, dampak, dan komunikasi memiliki pengaruh terhadap keputusan pembelian secara positif. Semakin besar pengaruh variabel $\mathrm{X}$ semakin besar pula keputusan pembelian tiket pesawat melalui website Tiket.com. Didukung juga dengan hasil uji hipotesis yaitu uji t dan uji $\mathrm{f}$.

Empati $(x 1)$ berpengaruh positif dan signifikan terhadap keputusan pembelian (y) tiket pesawat, dengan kata lain semakin baik informasi yang diberikan oleh tiket.com, semakin besar pula pengaruh terhadap keputusan pembelian tiket pesawat di tiket.com.

Penelitian ini sesuai dengan penelitian yang dilakukan oleh Muhammad Rusyady (2017) yang menyatakan bahwa, faktor empati merupakan salah satu faktor yang dapat mempengaruhi keputusan pembelian. Wisatawan akan mencari informasi mengenai promosi -promosi sebelum memutuskan untuk membeli sesuatu.

Promosi mengenai tiket pesawat yang dilakukan oleh tiket.com sudah sangat baik. Pada jaman sekarang informasi apapun bisa di dapat dengan mudah dan cepat. Dari 200 responden 
terdapat 65 orang yang menyatakan mendapat informasi mengenai tiket.com melalui iklan di televisi. Itu membuktikan bahwa, informasi tersebar luas dengan sangat cepat melalui media - media universal seperti halnya televisi ini.

Persuasi $(x 2)$ berpengaruh positif dan signifikan terhadap keputusan pembelian (y) tiket pesawat, dengan kata lain semakin bagus visualisasi promosi yang dilakukan oleh tiket.com, semakin besar pula pengaruh terhadap keputusan pembelian tiket pesawat di tiket.com.

Penelitian ini sesuai dengan penelitian yang dilakukan oleh Primasita Arini Khairunnisa (2015), bahwa faktor persuasi berpengaruh positif dan signifikan terhadap keputusan pembelian.

Persuasi merupakan salah satu faktor yang dilihat wisatawan sebelum memutuskan keputusannya. Karena melihat iklan promosi yang ditampilkan, wisatawan dapat terpengaruh dalam mengambil keputusan. Visualisai promosi yang ditampilkan memiliki peran penting, mereka melihat dari segi uniknya penyampaian iklan seperti, tema, warna, desain, dan logo ciri khas suatu produk. Tiket.com dalam penyampaian promosinya sudah menampilkan visualisasi yang unik dengan tema, warna dan desain menunjukan ciri khas Tiket.com.

Dampak (x3) berpengaruh positif dan signifikan terhadap keputusan pembelian (y) tiket pesawat, dengan kata lain semakin bagus dampak promosi yang dilakukan oleh tiket.com, semakin besar pula pengaruh terhadap keputusan pembelian tiket pesawat di tiket.com.

Penelitian ini juga sesuai dengan Angelia Sumampouw (2013) yang menyatakan bahwa, faktor dampak berpengaruh positif dan signifikan terhadap keputusan pembelian.

Dampak merupakan salah satu faktor yang dirasakan oleh wisatawan sebelum memutuskan keputusannya. Karena dimensi (impact) menunjukkan, apakah suatu merek dapat terlihat menonjol dibandingkan merek lain pada kategori yang serupa dan iklan akan mampu melibatkan konsumen dalam pesan yang disampaikan. Konsumen dapat memiliki empat tingkat pengetahuan produk, yaitu : kelas produk, bentuk produk, merek, dan model. Selain itu, konsumen juga dapat memiliki tiga jenis pengetahuan produk, yaitu pengetahuan tentang ciri atau karakter produk, konsekuensi atau manfaat positif menggunakan produk, dan nilai yang akan dipuaskan atau dicapai suatu produk (AC Nielsen, 2000). Tiket.com telah membuat iklan - iklan dengan isi (konten) yang menarik dan unik, dengan mengambil tema "liburan seru bisa kemana aja".

Komuikasi (x4) berpengaruh positif dan signifikan terhadap keputusan pembelian (y) tiket pesawat, dengan kata lain semakin bagus komunikasi yang dilakukan oleh tiket.com, semakin besar pula pengaruh terhadap keputusan pembelian tiket pesawat di tiket.com

Penelitian ini juga sesuai dengan Angelia Sumampouw (2013) yang menyatakan bahwa, faktor komunikasi berpengaruh positif dan signifikan terhadap keputusan pembelian. Komunikasi merupakan informasi tentang kemampuan konsumen dalam mengingat pesan utama yang disampaikan, pemahaman konsumen, serta kesan yang ditinggalkan pesan tersebut.

Tiket.com dalam promosinya memiliki suatu slogan yang gampang di ingat serta dapat mempengaruhi keputusan pembelian, yaitu "kemana pun, tiket.com aja". Slogan ini dibuat oleh pihak tiket.com agar konsumen gampang mengingat situs tiket.com jika ingin bepergian atau berwisata.

\section{SIMPULAN}

Berdasarkan pembahasan hasil penelitian ini, adapun simpulan yang dapat ditarik adalah sebagai berikut.

Karakteristik pengguna situs tiket.com dari asalnya didominasi oleh wisatawan Jakarta dengan jumlah 40 orang 
(20\%), dengan jenis kelamin perempuan dengan jumlah 120 orang $(60 \%)$, dengan wisatawan yang belum menikah dengan jumlah 140 orang (70\%). Dilihat dari usia didominasi oleh wisatawan yang berusia $17 \mathrm{~s} / \mathrm{d} 27$ tahun dengan jumlah 150 orang (75\%). Adapun berdasarkan pendidikan didominasi oleh wisatawan yang berlatar belakang pendidikan S1 dengan jumlah 93 orang $(47 \%)$, dilihat dari profesi didominasi oleh karyawan dengan jumlah 83 orang $(41,5 \%)$. Jika dilihat berdasarkan sumber informasi didominasi melalui televisi dengan jumlah 65 orang (32,5\%).

Efektivitas promosi Tiket.com dengan EPIC model, dari segi Empathy (x1) berpengaruh positif dan signifikan terhadap keputusan pembelian (y) tiket pesawat. Dengan nilai signifikansi sebesar 0,001 , dimana nilai ini kurang dari $\alpha=$ 0,05 dan thitung sebesar 3,299 lebih besar dari ttabel sebesar 1,652. Persuasion (x2) berpengaruh positif dan signifikan terhadap keputusan pembelian (y) tiket pesawat. Dengan nilai signifikansi sebesar 0,001 dimana nilai ini kurang dari $\alpha=0,05$ dan thitung sebesar 3,326 lebih besar dari $\mathrm{t}$ tabel sebesar 1,652. Impact (x3) berpengaruh positif dan signifikan terhadap keputusan pembelian (y) tiket pesawat. Dengan nilai signifikansi sebesar 0,041 dimana nilai ini kurang dari $\alpha=0,05$ dan thitung sebesar 2,056 lebih besar dari t tabel sebesar 1,652. Communication (x4) berpengaruh positif dan signifikan terhadap keputusan pembelian (y) tiket pesawat. Dengan nilai signifikansi sebesar 0,000 , nilai ini kurang dari $\alpha=0,05$ dan thitung sebesar 5,321 lebih besar dari ttabel sebesar 1,652. Dengan EPIC model tersebut segi communication merupakan faktor yang paling besar mempengaruhi keputusan wisatawan untuk membeli tiket melalui website Tiket.com. Hal ini dikarenakan komunikasi yang terdapat dalam promosi Tiket.com mudah untuk dimengerti dan melekat pada ingatan wisatawan untuk menggunakan website Tiket.com ketika membeli tiket pesawat jika melakukan perjalanan wisata.

\section{SARAN}

Berdasarkan pembahasan pada penelitian ini, maka peneliti mencoba memberikan saran - saran. Adapun saran saran yang dapat diberikan :

Berdasarkan hasil penelitian, diketahui bahwa secara keseluruhan promosi yang dilakukan tiket.com sudah sangat baik. Disarankan kepada pihak tiket.com agar memperhatikan faktor impact (dampak) yaitu, dengan meningkatkan kualitas iklan agar terlihat lebih menonjol dibandingkan merk lain. Pihak tiket.com juga hendak memperhatikan hal yang dianggap penting dalam meningkatkan keputusan pembelian, tidak berfokus terhadap satu atau dua faktor tertentu demi keberlangsungan dan menghadapi persaingan dengan perusahaan sejenis lainya.

Adapun saran akademis bagi peneliti selanjutnya yaitu, penelitian lebih lanjut diharapkan dapat menggali variabel yang lain dengan jumlah sampel yang lebih besar agar ditemukan komparatif studi yang dapat memperkaya hasil penelitian ini. 


\section{Kepustakaan}

Adi, Suroto. 2014. "Evaluation On The Effectiveness of The Web Technology Usage In Promoting And Marketing Indonesia Tourism" dalam Journal of Theoretical and Applied Information Technology, 31 Oktober 2014. Vol. 68 No.3.

Ali Hasan, S.E., M.M., 2015, Tourism Marketing, Center for Academic Publishing Service, Yogyakarta.

Anusha,G. 2016. "Effectiveness Of Online Advertising" dalam International Journal of Research Granthaalayah, Vol. 4, No. 3: SE (2016): 14-21.

Campbell. 1989. Riset dalam Efektivitas Organisasi. Simamora. Jakarta: Erlangga.

Chaffey, Dave; et al. 2002. Internet Marketing. Pearson Education Limited,.England

Durianto, Darmadi et al. 2003. Invasi Pasar dengan Iklan Yang Efektif. Jakarta, PT Gramedia Pustaka Utama.

Elbert, Ronald J. \& Ricky W. Griffin. 2009. Business. New Jersey: Prentice - Hall

Ghulam Shabbir Khan Niazi, Javaria Siddiqui, Burhan Ali Shah, Ahmed Imran Hunjra.2012. "Effective Advertising and its Influence on Consumer Buying Behavior" dalam Information Management and Business Review Vol. 4, No. 3, pp. 114-119, Mar 2012 (ISSN 22203796).

Gibson, R. F. 1984. Pinsiple of Composite Material Mechanics. New York: Mc Graw Hill.

Hidayat. 1986. Definisi Efektifitas. Bandung: Angkasa.

Ismayanti. 2010. Pengantar Pariwisata. Jakarta: Grasindo

Kusmayadi dan Sugiarto, Endar. 2000. Metodologi Penelitian dalam Bidang Kepariwisataan. Jakarta: PT. Gramedia Pustaka Utama.
Kiswati Sri. 2010. Study Tentang Sikap Konsumen Atas Merek Tolak Angin Pada Mahasiswa FE Undip Semarang. (Tesis). Semarang: Universitas Diponegoro Semarang.

Khairunnisa Arini. 2015. Analisis Pengaruh Dimensi Epic Pada Iklan Spanduk Terhadap Keputusan Pembelian (Studi Kasus pada CV Cahaya Bandung). (Skripsi) Jakarta: Universitas Bakrie.

Kotler, Philip. 2000. Manajemen Pemasaraan. Edisi Milennium. Jakarta: Prenhallindo.

Kotler dan Amstrong. 2006. Prinsipprinsip Pemasaran. Edisi Ke 12. Jakarta: Erlangga.

Kotler dan Keller. 2008. Manajemen Pemasaran. Edisi ke 13 Jilid 2. Jakarta: Erlangga.

Margono. 2003. Metode Penelitian Pendidikan. Jakarta: PT Asdi Mahasatya.

Mursalim. 2013. Analisis Efektivitas Iklan Media Online Pada PT Surveyor Indonesia Kanwil Makasar. (Skripsi). Makasar : Universitas Hasanuddin.

Nur Hasanah, Lukito Edi Nugroho, Eko Nugroho. 2015. "Analisis Efektivitas Iklan Jejaring Sosial sebagai Media Promosi Menggunakan EPIC Model" dalam Scientific Journal Infromatics Semarang State University, Vol. 2, No. 2, (2015).

Nazir, Moh., 2005, Metode Penelitian. Bogor: Ghalia Indonesia.

Putra, Adi Cahaya I Gede.2016. Pengaruh Harga Dan Citra Merek Terhadap Keputusan Pembelian Tiket Maskapai Citilink Oleh Wisatawan Nusantara Di Bandara Ngurah Rai, Bali. (Skripsi). Denpasar: Universitas Udayana.

R. Achmad Basah. 2012. Kualitas Pelayanan Penjualan Tiket Pada PT. Bonanza Pekanbaru Holiday Tour \& Travel. (Skripsi) Surakarta: Universitas Muhammadiyah . 
Rusyady, Muhamad. 2017. Pengaruh Efektifitas Iklan Terhadap Keputusan Pembelian Kartu Perdana Telkomsel (Studi di Kelurahan Sanua Kecamatan Kendari Barat). (Skripsi). Kendari : Universitas Halu Oleo.

Sumampouw Angelia. 2013. "Analisis Efektivitas Iklan Televisi Produk Aqua Dengan Menggunakan Metode Epic Model Dan Pengaruhnya Terhadap Keputusan Pembelian Produk Aqua Di Kota Manado" dalam Jurnal Riset Bisnis Dan Manajemen. Universitas Sam Ratulangi, Vol. 1, No. 3, (2013).

Susanto, Agus. 2013. Pengaruh Promosi, Harga Dan Inovasi Produk Terhadap Keputusan Pembelian Pada Batik Tulis Karangmlati Demak. (Skripsi). Semarang : Universitas Negeri.

Sangadji dan Sopiah. 2013. Perilaku Konsumen. Yogyakarta: Andi.

Sugiyono, 2009. Metode Penelitian Kuantitatif, Kualitatif, dan $R \& D$. Bandung: Alfabeta.

Sanjaya, Ridwan. Josua Tarigan. 2009. Creative Digital Marketing Teknologi Berbiaya Murah, Inovatif dan Berdaya hasil gemilang. Jakarta: P.T Alex Media Komputindo.

Septiani, Ni Luh Putu. 2017. Efektivitas Penggunaan Saluran Bali Go Live Sebagai Media Promosi Pariwisata Bali Berbasis Digital. (Skripsi) Denpasar : Universitas Udayana.

Sedarmayanti, 2009. Sumber Daya Manusia dan Produktivitas Kerja. Bandung: CV Mandar Maju.

Suwena, I Ketut dan Widyatmaja, Ngr I Gst. 2017. Pengetahuan Dasar Ilmu Pariwisata. Denpasar : Pustaka Larasan.

Sugiyono, 2014. Metode Penelitian Kuantitatif, Kualitatif, dan R\&D. Bandung: Penerbit Alfabeta.
Sujarweni, 2015. SPPS Untuk Penelitian. Yogyakarta: Pustaka Baru Press

Supranto, J., 2000. Statistik, Teori dan Aplikasi. Jakarta : Erlangga.

Tasneem, Sadia dan Fatema, Kaniz. 2015. "Effectiveness of Digital Marketing in the Challenging Age: An Empirical Study" dalam International Journal of Management Science and Business Administration, Volume 1. Issue 5, Pages 69-80 